\title{
PENGARUH BIAYA PRODUKSI TERHADAP HARGA JUAL PRODUK MARMER PADA POLITEKNIK ACEH SELATAN
}

\author{
Devi Satria Saputra \\ Dosen Teknik Industri Politeknik Aceh Selatan, Tapaktuan \\ Email : deviss_aceh@yahoo.com.devisatria15@gmail.com
}

\begin{abstract}
Industri UPT Batu Marmer Politeknik Aceh mengalami ketidakmampuan dalam menghitung unsur biaya produksi secara menyeluruh, hal ini dapat dilihat dalam penghitungan biaya tenaga kerja dan biaya overhead pabrik belum dilakukan secara betul. Tujuan yang ingin dicapai pada penelitian ini adalah untuk mengetahui sejauh mana pengaruh biaya produksi terhadap harga jual. Populasi dalam penelitian ini adalah semua Produk industri kecil Batu Marmer yang ada di Kampus Politeknik Aceh Selatan, penelitian ini dikategorikan penelitian sensus. Teknik pengumpulan data yang digunakan adalah wawancara. Teknik analisis data menggunakan persamaan regresi linier sederhana, pembuktian hipotesis dengan menggunakan uji t dan koefisien determinasi dengan menggunakan alat bantu program SPSS 11,0 for windows. Persamaan regresi sederhana dapat diketahui adanya pengaruh positif biaya produksi terhadap harga jual. Artinya setiap kenaikan biaya produksi akan diikuti pula dengan kenaikan harga jual dan penurunan biaya produksi akan diikuti pula dengan penurunan harga jual. Biaya produksi dengan harga jual terdapat pengaruh sebesar 93,8 \% sedangkan sisanya dipengaruhi oleh variabel lain, faktor ekstern seperti elastisitas permintaan, sasaran produk dan persaingan pasar, selera konsumen, kondisi perekonomian, pengawasan pemerintahan. Saran yang dapat diberikan penulis bagi industri UPT Batu Mamer sebaiknya dalam penghitungan biaya produksi memasukkan semua unsur biaya selama proses produksi dengan terperinci dalam satu rangkaian produksi dan melakukan pembenahan administrasi atau mengadakan pembukuan dengan baik.
\end{abstract}

Keywords: Biaya Produksi, Laba yang Diinginkan, Harga Jual

\section{Pendahuluan}

\subsection{Latar Belakang Masalah}

Perkembangan dunia usaha sekarang ini sangat pesat. Hal ini ditandai dengan tajamnya persaingan dalam dunia usaha guna mempertahankan dan meningkatkan usahanya. Dengan tajamnya persaingan tersebut perusahaan dituntut mampu menghadapi persaingan yang ada. Demikian juga dalam dunia usaha khususnya industri kecil. Industri kecil diharapkan mempunyai kebijakan dan strategi untuk dapat mempertahankan dan meningkatkan usahanya.

Industri kecil dan menengah termasuk industri kerajinan dan industri rumah tangga perlu dibina menjadi usaha yang makin efisien dan mampu berkembang, agar dapat meningkatkan pendapatan masyarakat, membuka lapangan kerja dan makin mampu meningkatkan perannya dalam penyediaan barang dan jasa serta berbagai komponen, baik untuk keperluan pasar dalam negeri maupun pasar luar negeri. Pengembangan industri kecil dan menengah perlu diberi kemudahan baik dalam permodalan, perijinan maupun pemasaran serta ditingkatkan keterkaitan dengan industri yang berskala besar secara efisien menguntungkan melalui pola kemitraan dalam usaha meningkatkan peran dan kedudukannya dalam pembangunan industri.

Penentuan harga jual yang tidak tepat sering berakibat fatal pada masalah keuangan perusahaan dan akan mempengaruhi kontinuitas usaha perusahaan. Ketidaktepatan tersebut akan menimbulkan resiko pada perusahaan, misalnya kerugian yang terus menerus atau menimbunnya produk di gudang karena macetnya pemasaran. Untuk itu setiap perusahaan harus menetapkan harga jualnya secara tepat karena harga merupakan satusatunya unsur bauran pemasaran yang memberikan pemasukan atau pendapatan bagi perusahaan. Pada hakekatnya perusahaan dalam menjual produknya harus dapat mencapai keuntungan yang diharapkan, sehingga perusahaan dalam menjual produknya harus menetapkan harga jual.

Biaya produksi juga merupakan dasar yang memberikan perlindungan bagi perusahaan dari kemungkinan kerugian. Kerugian akan mengakibatkan suatu usaha tidak dapat tumbuh dan bahkan akan dapat mengakibatkan perusahaan harus menghentikan kegiatan bisnisnya. Untuk menghindari kerugian, salah satu cara adalah dengan berusaha memperoleh pendapatan yang paling tidak dapat menutup biaya produksi. Dengan demikian, sangat penting memperhitungkan biaya produksi dan 
menetapkan harga jual produk dengan tepat untuk memberikan perlindungan bagi perusahaan dari kemungkinan kerugian.

Berdasarkan survei awal pada tanggal 10 Desember 2015, penulis melakukan wawancara dengan Bapak Asbahrul Amri, ST.M.Sc sebagi Kepala UPT Batu Marmer Politeknik Aceh Selatan . Dengan melakukan tanya jawab secara langsung mengenai Batu Marmer, maka dapat diketahui bahwa dalam menentukan harga jual hasil produk Batu Maremer, pengrajin kurang memperhatikan faktorfaktor yang mempengaruhi harga jual produknya. Hal ini nampak dalam penghitungan biaya produksi misalnya dalam penghitungan biaya belum dilakukan secara betul. Ada biaya yang belum diperhitungkan dalam penghitungan biaya produksi, seperti biaya tenaga kerja dan bahan baku dalam usaha. Padahal dalam perhitungan biaya produksi semua unsur yang membentuk biaya produksi seharusnya dimasukkan misalnya, gaji pimpinan maupun biaya tenaga kerja langsung. Pemakaian tenaga kerja langsung belum diperhitungkan karena dikerjakan oleh anggota Tim kerja, begitu juga menyangkut jam kerja mereka kurang mengenal waktu.

Selain itu banyak juga industri batu marmer yang belum memperhitungkan biaya overhead pabrik dengan benar. Hal itu terlihat dalam memperhitungkan biaya overhead pabrik banyak unsur-unsur biaya overhead pabrik yang tidak diperhitungkan, misalnya biaya reparasi mesin atau peralatan pabrik, dan biaya pemeliharaan mesin.

\subsection{Perumusan Masalah}

Biaya produksi dan laba yang diinginkan akan berperan dalam mempertimbangkan terbentuknya harga jual. Perolehan laba yang diinginkan secara maksimal pada umumnya merupakan tujuan utama dari kegiatan suatu perusahaan.. Salah satu faktor yang memiliki kepastian dalam menentukan harga jual adalah biaya produksi. Biaya produksi memberikan informasi batas bawah terhadap harga jual yang akan ditentukan. Perusahaan akan mengalami kerugian bila harga jual berada di bawah biaya produksi. Kerugian yang timbul akibat harga jual di bawah biaya produksi dalam jangka waktu tertentu akan mengakibatkan terhambatnya suatu pertumbuhan usaha. Dengan demikian perusahaan memerlukan informasi tentang biaya produk dalam pengambilan keputusan harga jual.

\subsection{Penegasan Istilah}

Maksud dari penegasan istilah untuk menghindari terjadinya perbedaan mengenai istilah-istilah yang ada dalam penelitian. Adapun istilah-istilah yang perlu diberikan batasan adalah:

a. Pengaruh
Pengaruh adalah daya yang ada atau timbul dari sesuatu (orang, benda dan sebagainya) yang berkuasa atau berkaitan yang ikut membentuk watak, kepercayaan, perbuatan seseorang (kamus besar bahasa indonesia edisi kedua).

b. Biaya Produksi

Biaya produksi adalah pengorbanan sumber ekonomi, yang diukur dalam satuan uang, yang telah terjadi untuk tujuan tertentu atau dalam arti sempit biaya produksi dapat diartikan sebagai pengorbanan sumber ekonomi untuk memperoleh aktiva (Mulyadi, 1991:8-9.

c. Harga Jual

Harga jual adalah harga yang diperoleh dari penjumlahan biaya produksi, biaya non produksi serta laba yang diharapkan (Mulyadi 2002:79).

d. Industri Batu Marmer

Industri kecil adalah industri yang berskala kecil yang dikelompokkan berdasarkan jumlah tenaga kerja yang terlibat tanpa memperhatikan besar modal.

\subsection{Tujuan penelitian}

Terkait dengan rumusan masalah yang telah dikemukakan, maka peneliti bertujuan ingin mengetahui sejauh mana biaya produksi berpengaruh terhadap harga jual pada industri Batu Marmer di UPT Marmer Politeknik Aceh Selatan.

\subsection{Kegunaan Penelitian}

Melalui penelitian ini diharapkan dapat memberikan manfaat ganda yaitu manfaat teoritis maupun manfaat praktis.

a. Guna Teoritis

Penelitian ini ingin menganalisis teori ekonomi tentang harga jual. Khususnya biaya produksi pada industri UPT Marmer Politeknik Aceh Selatan. Melalui penelitian ini diharapkan memberikan informasi lebih lanjut bagi peneliti selanjutnya.

b. Guna Praktis

Hasil penelitian ini diharapkan akan menjadikan masukan bagi industri UPT Marmer Politeknik Aceh Selatan.dalam menentukan kebijakan harga jual dengan memperhatikan faktor-faktor yang mempengaruhi

\section{Metode dan Peralatan}

\subsection{Populasi}

Populasi adalah keseluruhan subjek penelitian (Arikunto, 2000:108). Di dalam suatu penelitian apabila peneliti ingin meneliti semua elemen yang 
ada dalam wilayah penelitian, maka peneliti ini merupakan penelitian populasi. Studi atau penelitiannya juga disebut dengan studi populasi atau studi kasus. Populasi dalam penelitian ini adalah keseluruhan Industri UPT Batu marmer Politeknik Aceh Selatan, sehingga penelitian ini dikategorikan penelitian sensus.

\subsection{Sampel}

Sampel adalah sebagian atau wakil populasi yang diteliti ( Arikunto, 2000:109). Adapun sampel yang digunakan dalam penelitian ini adalah penelitian sensus yaitu keseluruhan Produk Batu Marmer yang di produksi ada 5 katagori.

\subsection{Operasionalisasi Variabel}

Variabel adalah objek penelitian atau sesuatu yang menjadi titik perhatian (Arikunto, 2000:96). Variabel dibedakan menjadi dua yaitu varibel bebas dan variabel terikat. Variabel bebas (X) adalah variabel yang mempengaruhi. Variabel terikat (Y) adalah akibat (Arikunto, 2000:97).

Adapun dalam penelitian ini sebagai variabel bebasnya yaitu biaya produksi $\left(\mathrm{X}_{1}\right)$ sedangkan variabel terikat yaitu harga jual (Y).

Untuk mewujudkan suatu kesatuan fikir atau untuk menghindari bermacam-macam interprestasi maka perlu ditegaskan istilah berkaitan dengan penelitian ini. Karena banyak faktor yang mempengaruhi penentuan harga jual maka dalam penelitian ini diambil faktor biaya produksi saja dengan alasan faktor tersebut merupakan faktor yang pasti dan mudah diperhitungkan. Selain itu juga karena keterbatasan penulis. Adapun definisi variabel penelitian ini adalah sebagai berikut:

\section{a. Biaya Produksi $\left(\mathrm{X}_{1}\right)$}

Biaya produksi yang dimaksud dalam penelitian ini adalah biaya bahan baku, biaya tenaga kerja, dan biaya overhead pabrik yang dikeluarkan dalam rangka proses produksi yaitu mengolah bahan baku menjadi produk jadi Batu Marmer di Politeknik Aceh Selatan.

b. Harga Jual (Y)

Harga jual yang dimaksud dalam penelitian ini adalah nilai tukar atau nilai akhir barang yang merupakan penjumlahan dari biaya-biaya produksi dan biaya lain untuk memproduksi suatu barang ditambah dengan sejumlah keuntungan yang diinginkan.dari produk Batu Marmer yang ada di Politeknik Aceh Selatan yang ditentukan dengan uang.

\subsection{Metode Pengumpulan Data}

Untuk memperoleh data yang diperlukan dalam penelitian ini penulis hanya menggunakan metode wawancara. Karena dalam penelitian ini memang para pemilik industri Batu Marmer tidak memiliki sumber berupa dokumentasi. Wawancara merupakan bagian teknik komunikasi dimana pencari data mengadakan tanya jawab terhadap responden untuk menggali data yang diperlukan. Dalam penelitian ini digunakan untuk memperoleh informasi yang diperlukan. Hal ini dimaksudkan agar data yang di maksud peneliti itu sesuai dengan harapan peneliti.

\subsection{Metode Analisis Data}

Model analisis data yang digunakan adalah analisis regresi sederhana, persamaan linier sederhana menunjukkan hubungan antara dua variabel, yaitu variabel $X$ sebagai variabel independen dan variabel Y sebagai variabel dependen (Algifari, 2000:9). Regresi linier sederhana digunakan untuk mengetahui pengaruh biaya produksi terhadap harga jual. Model persamaan regresi yang digunakan dalam pengujian adalah:

a. Persamaan Regresi Sederhana

$$
\begin{aligned}
& \quad \mathbf{Y}=\mathbf{a}+\mathbf{b X}+\mathbf{e} \\
& \text { dengan: } \\
& \mathrm{Y}=\text { harga jual } \\
& \mathrm{a}=\text { Intersep (titik potong kurva terhadap sumbu } \mathrm{Y} \text { ) } \\
& \mathrm{b}=\text { kemiringan (slope) kurva linier } \\
& \mathrm{X}=\text { Biaya produksi } \\
& \mathrm{e}=\text { Error Term } \\
& \text { untuk menghitung nilai a b dan e ini menggunakan } \\
& \text { program komputer statistik yaitu SPSS. }
\end{aligned}
$$

\section{b. Uji hipotesis}

\section{1) Uji t-statistik}

Uji t digunakan untuk menguji koefisien regresi secara parsial dari variabel independennya. Nilai $\mathrm{t}$ masing-masing koefisien regresi dapat diketahui dari hasil penghitungan komputer.

Untuk menentukan nilai t-statistik tabel ditentukan tingkat signifikasi $5 \%$ dengan $\mathrm{df}=(\mathrm{n}-\mathrm{k}-1)$ dimana $\mathrm{n}$ adalah jumlah observasi dan $\mathrm{k}$ adalah jumlah variabel termasuk intersep dengan kriteria uji adalah:

Jika $\mathrm{t}$ hit $>\mathrm{t}$ tabel, maka Ho ditolak

Jika $\mathrm{t}$ hit $<\mathrm{t}$ tabel, maka Ho diterima

Hipotesisnya yaitu :

$$
\begin{array}{r}
\text { Ho }=\beta_{1}=0 \\
\beta_{2}=0
\end{array}
$$

Tidak terdapat pengaruh yang signifikan dari variabel independen $(\mathrm{X})$ terhadap variabel dependen (Y)

$$
\text { Ho } \neq \beta_{1} 0
$$


$\beta_{2}$

Artinya terdapat pengaruh yang signifikan dari variabel independen $(\mathrm{X})$ terhadap variabel dependen (Y).

\section{2) Koefisien determinasi}

Ukuran statistik yang dapat menggambarkan hubungan antara suatu variabel dengan variabel lain adalah koefisien determinasi dan koefisien korelasi. Koefisien determinasi diberi simbol $\left(\mathrm{r}^{2}\right)$ dan koefisen korelasi diberi symbol r. Koefisien determinasi adalah salah satu nilai statistik yang dapat digunakan untuk mengetahui apakah ada hubungan pengaruh antara dua variabel.

Koefisien determinasi $\left(\mathrm{r}^{2}\right)$ dari hasil regresi sederhana menunjukkan tingkat kejelasan yang dapat diberikan oleh model tersebut terhadap perubahan variabel dependen. Secara umum nilai $\mathrm{r}^{2}$ terletak pada nilai 0 sampai dengan $1\left(0<\mathrm{r}^{2}<1\right)$. Nilai koefisien determinasi menunjukkan persentase variasi nilai variabel dependen yang dapat dijelaskan oleh persamaan regresi yang dihasilkan.

Semakin mendekat nol besarnya koefisien determinasi $\left(\mathrm{r}^{2}\right)$ suatu persamaan regresi, semakin kecil pula pengaruh semua variabel independen terhadap nilai variabel dependen (dengan kata lain semakin kecil kemampuan model dalam menjelaskan perubahan nilai variabel dependen). Sebaliknya, semakin mendekat satu besarnya koefisien determinasi $\left(\mathrm{r}^{2}\right)$ suatu persamaan regresi, semakin besar pula pengaruh semua variabel independen terhadap nilai variabel dependen.

\section{Hasil dan Pembahasan}

\subsection{Hasil Penelitian}

Bab ini merupakan hasil data industri Produk Batu Marmer Politeknik Aceh Selatan yang meliputi biaya produksi dan harga jual pada tahun 2015. Hasil penelitian ini akan memaparkan hasil persamaan regresi sederhana.

\section{Hasil Persamaan Regresi Sederhana}

Hasil analisis regresi linier sederhana dengan menggunakan program SPSS release 11,0 pada penelitian ini diperoleh persamaan regresi yang menyatakan persamaan pengaruh biaya produksi $\left(\mathrm{X}_{1}\right)$ terhadap harga jual (Y) sebagai berikut:

Tabel 1. Analisis Pengaruh Biaya Produksi Terhadap Harga Jual

\begin{tabular}{|l|c|c|c|c|c|}
\hline \multirow{2}{*}{ Model } & \multicolumn{2}{|c|}{$\begin{array}{c}\text { Unstandardized } \\
\text { Coefficient }\end{array}$} & \multirow{2}{*}{$\mathrm{t}$} & Sig & $\mathrm{r}^{2}$ \\
\cline { 2 - 3 } & $\mathrm{B}$ & Sid Error & & & \\
\hline Constant & $1.2 \mathrm{E}+07$ & $1.8 \mathrm{E}+07$ & 640 & 527 & 0.938 \\
\hline $\begin{array}{l}\text { Biaya } \\
\text { Produksi }\end{array}$ & 1.360 & 0.60 & 22.732 & 000 & \\
\hline
\end{tabular}

Hasil analisis regresi tersebut diperoleh model regresi untuk menyatakan persamaan pengaruh biaya produksi $(\mathrm{X})$ terhadap harga jual $(\mathrm{Y})$ yaitu:

$$
\mathrm{Y}=\mathbf{1 . 2 \mathrm { E } + 0 7 + 1 . 3 6 0}
$$

dari persamaan regresi ini diperoleh $\mathrm{t}_{\text {hitung }}$ sebesar 22,732. Sedangkan nilai $t_{\text {tabel }}$ dari $\mathrm{df} 1=1$ dan $\mathrm{df} 2=34$ dengan taraf signifikan 0,05 adalah sebesar 1,691. Maka dapat diketahui bahwa $\mathrm{t}_{\text {hitung }}=22,732>\mathrm{t}_{\text {tabel }}$ $=1.691$ yang berarti terdapat adanya pengaruh biaya produksi terhadap harga jual yaitu sebesar $93,8 \%$.

\section{Koefisien determinasi $\left(\mathrm{r}^{2}\right)$}

Koefisien determinasi $\left(\mathrm{r}^{2}\right)$ dari hasil regresi sederhana menunjukkan tingkat kejelasan yang dapat diberikan oleh model tersebut terhadap perubahan variabel dependen. Dengan melihat hasil SPSS release 11,0 dari medel summary dapat diketahui bahwa nilai $\left(\mathrm{r}^{2}\right)$ sebesar 0,938 . Dengan nilai koefisien determinasi $\left(\mathrm{r}^{2}\right)$ yang sebesar 0,938 yang berarti mendekati angka satu, menunjukkan bahwa biaya produksi sangat besar pengaruhnya terhadap harga jual.

Artinya pengaruh variabel (X) yaitu biaya produksi terhadap variabel (Y) harga jual adalah sebesar 93,8\%, sedangkan sisanya sebesar 6,2\% dipengaruhi oleh variabel lain selain biaya produksi, misalnya kondisi pasar, persaingan, permintaan, penawaran, selera konsumen dan pengawasan pemerintah. Makna dari persamaan regresi tersebut adalah setiap adanya kenaikan biaya produksi sebesar satu rupiah maka harga jual akan naik sebesar $\mathrm{Rp}$ 1,360 .

3. Hasil Data Biaya Produksi dan Harga Jual Pada Industri Marmer tahun 2015

Pencapaian harga jual setiap bulan pada tahun 2015 dari Produk Batu marmer Politeknik Aceh Selatan dalam tabel berikut :

Tabel 2 Harga Jual Pe rbulan Tahun 2015
\begin{tabular}{|c|c|}
\hline Bulan & Jumlah \\
\hline Januari & Rp. 30.000 .000 \\
\hline Febuari & Rp. 30.000 .000 \\
\hline Maret & Rp. 30.000 .000 \\
\hline April & Rp. 35.000 .000 \\
\hline Mei & Rp. 35.000 .000 \\
\hline Juni & Rp. 38.000 .000 \\
\hline Juli & Rp. 38.000 .000 \\
\hline Agustus & Rp. 40.000 .000 \\
\hline September & Rp. 42.000 .000 \\
\hline Oktober & Rp. 45.000 .000 \\
\hline November & Rp. 48.500 .000 \\
\hline Desember & Rp. 55.000 .000 \\
\hline Total Harga Jual & Rp. 467.000 .000 \\
\hline
\end{tabular}


Sedangkan untuk pengeluaran biaya produksi yang terdiri dari biaya bahan baku, biaya tenaga kerja dan biaya overhead pabrik adalah sebagai berikut:

Penggunaan biaya bahan baku tahun 2015 industri Produk Marmer Politeknik Aceh Selatan disajikan dalam Tabel sebagai berikut:

Tabel 3 Biaya Bahan Baku

\begin{tabular}{|c|c|}
\hline Bulan & BBB \\
\hline Januari & Rp. 5.000 .000 \\
\hline Febuari & Rp. 6.000 .000 \\
\hline Maret & Rp. 7.500 .000 \\
\hline April & Rp. 8.000 .000 \\
\hline Mei & Rp. 10.000 .000 \\
\hline Juni & Rp. 12.000 .000 \\
\hline Juli & Rp. 12.500 .000 \\
\hline Agustus & Rp. 15.000 .000 \\
\hline September & Rp. 18.000 .000 \\
\hline Oktober & Rp. 18.000 .000 \\
\hline November & Rp. 20.000 .000 \\
\hline Desember & Rp. 22.500 .000 \\
\hline Total Harga Jual & Rp.142.500.000 \\
\hline
\end{tabular}

Pengeluaran biaya tenaga kerja setiap bulan pada tahun 2015 industri produk batu marmer politeknik Aceh Selatan disajikan dalam tabel berikut:

Tabel 4 Biaya Tenaga Kerja

\begin{tabular}{|c|c|}
\hline Bulan & BTK \\
\hline Januari & Rp. 20.000.000 \\
\hline Febuari & Rp. 20.000.000 \\
\hline Maret & Rp. 20.000.000 \\
\hline April & Rp. 20.000.000 \\
\hline Mei & Rp. 20.000.000 \\
\hline Juni & Rp. 20.000.000 \\
\hline Juli & Rp. 20.000.000 \\
\hline Agustus & Rp. 20.000.000 \\
\hline September & Rp. 20.000.000 \\
\hline Oktober & Rp. 20.000.000 \\
\hline November & Rp. 20.000.000 \\
\hline Desember & Rp. 20.000.000 \\
\hline Total BTK & Rp.240.000.000 \\
\hline
\end{tabular}

Sedangkan untuk pengeluaran biaya overhead pabrik perbulan pada tahun 2015 dapat dilihat dalam Tabel berikut ini:

Tabel 5 Biaya Overhead Pabrik

\begin{tabular}{|c|c|}
\hline Bulan & BOP \\
\hline Januari & Rp. 1.600 .000 \\
\hline Febuari & Rp. 1.600 .000 \\
\hline Maret & Rp. 1.600 .000 \\
\hline April & Rp. 1.600 .000 \\
\hline Mei & Rp. 1.600 .000 \\
\hline
\end{tabular}

\begin{tabular}{|c|c|}
\hline Juni & Rp. 1.600 .000 \\
\hline Juli & Rp. 1.600 .000 \\
\hline Agustus & Rp. 1.600 .000 \\
\hline September & Rp. 1.800 .000 \\
\hline Oktober & Rp. 1.800 .000 \\
\hline November & Rp. 2.000.000 \\
\hline Desember & Rp. 2.500.000 \\
\hline Total BOP & Rp.20.900.000 \\
\hline
\end{tabular}

\subsection{Pembahasan}

Pada umumnya harga jual produk dan jasa ditentukan oleh perimbangan permintaan dan penawaran di pasar, sehingga biaya produksi dan laba bukan satu-satunya penentu harga jual. Selera konsumen, jumlah pesaing yang memasuki pasar, dan harga jual yang ditentukan pesaing, merupakan contoh faktor-faktor yang sulit untuk diramalkan, yang mempengaruhi pembentukan harga jual produk di pasar.

Hal ini sesuai dengan pendapat Swastha \& Irawan ( 2000) tentang faktor-faktor yang mempengaruhi harga jual, bahwa penentuan harga jual dipengaruhi oleh faktor laba, faktor produk, biaya produksi yang terdiri dari biaya bahan baku, biaya tenaga kerja dan biaya overhead pabrik, dan faktor ekstern, seperti elastisitas permintaan, sasaran produk, persaingan pasar dan pengawasan pemerintah.

\section{Pengaruh Biaya Produksi terhadap Harga Jual}

Hasil penelitian mengenai biaya produksi tahun 2015 pada industri batu mamer terdiri dari tiga macam yaitu biaya bahan baku, biaya tenaga kerja dan biaya overhead pabrik. Pengaruh biaya produksi terhadap harga jual ini sebesar 93,8\%..

Hal ini sudah sesuai dengan pendapat Mulyadi bahwa biaya mempunyai kepastian yang relatif tinggi dalam penentuan harga jual. Dalam penelitian ini diperoleh pengaruh yang sangat besar sekali, hal ini disebabkan karena penjualan produk berupa pesanan dengan penghitungan biaya variabel. Jadi biaya yang dikeluarkan akan berubah sebanding dengan kegiatan volume produksi.

Sedangkan biaya overhead pabrik pada industri produk marmer ini adalah biaya yang dikeluarkan untuk pembelian solar, Air, bahan pelicin, ada juga yang untuk membayar listrik apabila mesin yang digunakan untuk proses produksi marmer ini menggunakan listrik. Dalam penghitungan biaya overhead pabrik pada industri marmer ini juga kurang diperhitungkan dengan benar karena banyak unsur-unsur yang tidak dimasukkan dalam penghitungan biaya overhead pabrik, seperti biaya penyusutan peralatan mesin, biaya reparasi dan pemeliharaan mesin atau peralatan lainnya. 
Secara keseluruhan persentase tingkat pengeluaran biaya produksi untuk tahun 2015 adalah sebagai berikut:

Tabel 6. Persentase Biaya Produksi Tahun 2015

\begin{tabular}{|l|c|c|}
\hline \multicolumn{1}{|c|}{ Jenis Biaya } & \multicolumn{1}{|c|}{ Biaya } & $\begin{array}{c}\text { Persen } \\
\text { tase (\%) }\end{array}$ \\
\hline Biaya Bahan Baku & Rp 142.000.000 & 74,89 \\
\hline $\begin{array}{l}\text { Biaya Tenaga } \\
\text { Kerja }\end{array}$ & Rp 240.000.000 & 19,13 \\
\hline $\begin{array}{l}\text { Biaya Overhead } \\
\text { Pabrik }\end{array}$ & Rp 20.900.000 & 5,96 \\
\hline \multicolumn{1}{|c|}{ Total } & Rp 402.900.000 & $\mathbf{1 0 0}$ \\
\hline
\end{tabular}

(Sumber: data yang diolah)

Tabel tersebut menunjukkan bahwa biaya produksi yang terendah pada biaya overhead pabrik yaitu sebesar 5,96\%, untuk biaya tenaga kerja sebesar $19,13 \%$, sedangkan biaya produksi tertingginya untuk biaya bahan baku yaitu sebesar $74,89 \%$.

Dengan melihat hal tersebut jelas bahwa penghitungan biaya produksi tidak diperhitungkan dengan benar, terutama dalam penghitungan biaya tenaga kerja dan biaya overhead pabrik. Padahal menurut Mulyadi, bahwa yang memiliki kepastian relatif tinggi dalam penentuan harga jual adalah biaya produksi jadi dalam penghitungan biaya produksi harus diperhitungkan dengan lengkap dan benar agar peruasahaan tidak mengalami kerugian. Apabila banyak unsur-unsur biaya produksi yang tidak dimasukkan, dalam jangka waktu tertentu perusahaan mungkin akan mengalami kebangkrutan dan tidak dapat melanjutkan usahanya lagi.

\section{Kesimpulan}

Berdasarkan dari hasil penelitian dan pembahasan pada penelitian ini, maka dapat penulis simpulkan bahwa biaya produksi memberikan kontribusi terhadap harga jual sebesar 93,8\% pada industri produk batu mamer Politeknik Aceh Selatan, sedangkan sisanya sebesar 6,2\% dipengaruhi oleh variabel lain. Pengeluaran biaya produksi dalam penelitian ini adalah biaya bahan baku, biaya tenaga kerja dan biaya overhead pabrik dengan menggunakan biaya variabel.

\section{Daftar Pustaka}

[1] Mulyadi 1991 : 8-9 . Biaya Produksi. Penerbit. BPFE.Yogyakarta.

[2] Mulyadi, Akuntansi Biaya : Peneentuan Harga Pokok dan Pengendalian Biaya, Edisi 3 Penerbit BPFE . Yogyakarta.
[3] Mulyadi,Sriyadi. 2002 ; 79 , 2001 : 178 . Harga Jual. Penerbit BPFE . Yogyakarta.

[4] Halim, Abdul, dasar - dasar Akuntansi Biaya Edisi 3, Penerbit BPFE. Yogyakarta.

[5] Griffin, Ricky W. 2004. Manajemen. Edisi Ketujuh, Jilid 2, Penerjemah: Gina Gania, Jakarta: Erlangga.

[6] Mangkuprawira, Tb. Syafri. 2004. Manajemen Sumber Daya Manusia Strategik. Jakarta: Ghalia Indonesia.

[7] Widodo, Joko. 2011. Membangun Birokrasi Berbasis Kinerja. Malang: Bayumedia Publishing.

[8] Zainuddin. 2002. Komitmen Organisasi. Artikel online melalui www.e-psikologi.com. Diakses pada 13 Mei 2014. 